IZA DP No. 8972

Home-Ownership, Unemployed's Job Search Behavior and Post-Unemployment Outcomes

Marco Caliendo

Anne C. Gielen

Robert Mahlstedt

April 2015 


\title{
Home-Ownership, Unemployed's Job Search Behavior and Post-Unemployment Outcomes
}

\author{
Marco Caliendo \\ University of Potsdam, \\ $I Z A, D I W$ and IAB \\ Anne C. Gielen \\ Erasmus University Rotterdam \\ and IZA \\ Robert Mahlstedt \\ IZA and University of Potsdam
}

Discussion Paper No. 8972
April 2015

IZA

P.O. Box 7240

53072 Bonn

Germany

Phone: +49-228-3894-0

Fax: +49-228-3894-180

E-mail: iza@iza.org

Any opinions expressed here are those of the author(s) and not those of IZA. Research published in this series may include views on policy, but the institute itself takes no institutional policy positions. The IZA research network is committed to the IZA Guiding Principles of Research Integrity.

The Institute for the Study of Labor (IZA) in Bonn is a local and virtual international research center and a place of communication between science, politics and business. IZA is an independent nonprofit organization supported by Deutsche Post Foundation. The center is associated with the University of Bonn and offers a stimulating research environment through its international network, workshops and conferences, data service, project support, research visits and doctoral program. IZA engages in (i) original and internationally competitive research in all fields of labor economics, (ii) development of policy concepts, and (iii) dissemination of research results and concepts to the interested public.

IZA Discussion Papers often represent preliminary work and are circulated to encourage discussion. Citation of such a paper should account for its provisional character. A revised version may be available directly from the author. 


\title{
ABSTRACT \\ Home-Ownership, Unemployed's Job Search Behavior and Post-Unemployment Outcomes
}

\begin{abstract}
Although home-ownership has been shown to restrict geographic labor mobility and to affect job search behavior of unemployed, there is no evidence so far on how it affects their future re-employment outcomes. We use two waves of detailed German survey data of newly unemployed individuals to study the effect of home-ownership on the job search behavior of unemployed and their re-employment outcomes. We show that unemployed who own a home are less willing to move and also less likely to apply for jobs for which one would have to move. However, we do not find any evidence for compensations of their restricted mobility by more intensive (more search channels or applications) or different (more active or informal) search behavior. Furthermore, we find that home-ownership does not seem to harm the employment prospects of the unemployed. Although the re-employment probability in the short-run is slightly lower, we find that after one year home-owning unemployed have found better re-employment jobs, in terms of wages and job satisfaction, than their renting counterparts.
\end{abstract}

JEL Classification: J64, J61

Keywords: job search behavior, home-ownership, search effort, reservation wage, unemployment duration

Corresponding author:

Anne C. Gielen

Erasmus School of Economics

Erasmus University Rotterdam

PO Box 1738

3000 DR Rotterdam

The Netherlands

E-mail: gielen@ese.eur.nl

\footnotetext{
* This study uses the Scientific Use File of the IZA Evaluation Dataset Survey provided by the International Data Service Center (IDSC) of the Institute for the Study of Labor (IZA) (for more information, see Arni, Caliendo, Künn, and Zimmermann, 2014). We thank Andrew Oswald and Jeff Zabel for helpful comments and suggestions.
} 


\section{Introduction}

Labor market mobility is a highly debated topic in both academia and politics. In the face of increasing competition due to globalization, increasing labor market flexibility is high on the political agenda and various countries subsidize mobility as part of their active labor market policies (ALMP). One potential limitation for labor market flexibility could be home-ownership. Home-ownership can be an important barrier to flexibility in the labor market, if home-owners are less willing to move due to higher transaction costs of selling and buying their house. This aligns to the well-known finding of a positive relationship between home-ownership rates and aggregate unemployment rates by Oswald (1999). Although home-ownership is often claimed to also have positive externalities for the community (e.g. DiPasquale and Glaeser, 1999; Glaeser and Shapiro, 2003; Coulson and Fisher, 2009), the adverse effects might become very severe in times of economic crises. If people lose their job and if owning a house limits their mobility and hence reduces their opportunities to find a new job, home-ownership even aggravates the poor economic situation of these individuals. In fact, a recent study by Blanchflower and Oswald (2013) has found evidence for such negative externalities resulting from lower levels of labor mobility, longer commuting times and fewer new businesses. Furthermore, during the recent economic crisis housing prices have fallen dramatically in the US, which may have led to a "lock in" effect due to financial constraints faced by those whose housing debt exceeds the market value of their homes, although a recent study by Valetta (2013) did not find evidence for this.

If home-ownership restricts the geographic mobility of individuals, and hence limits the area in which they can look for a job, then it can be expected that unemployed homeowners will change their search behavior in order to improve the chance of finding a new job. First, when restricted to a small area with relatively few jobs, unemployed homeowners cannot send as many applications as they would have done if they were not bound to this area. However, they might choose to use either different (e.g. informal instead of formal search) or more search channels to increase the probability of finding a job. Second, unemployed home-owners might set a different reservation wage. On the one hand, they might lower their reservation wage in order to increase the probability of finding a job. On the other hand, they might have to set their reservation wages higher than renters because they have high financial obligations resulting from having a mortgage. Hence, the overall effect of home-ownership on reservation wages is unclear ex ante. Earlier studies (e.g. Munch, Rosholm, and Svarer, 2006; Morescalchi, 2014) have already shown that homeownership is associated with lower reservation wages, lower search intensity and different search methods. This restricted mobility and job search clearly can have an effect on future re-employment probabilities, and also may affect the quality of the re-employment job in terms of wages and job satisfaction. If owning a house would change the future job quality of unemployed job seekers, or if it would make unemployed face specific difficulties 
in finding a new job due to their restricted mobility, then additional policies might be needed to address these problems.

In this paper we focus on a large sample of newly unemployed job seekers in Germany and investigate their job search behavior and how having a restricted geographic area to search for new jobs affects their future re-employment outcomes. Next to the unemployment duration, we also examine re-employment wages and job satisfaction as indicators of job quality. This is an important contribution to the literature as we are not aware of any other study investigating this so far.

We use the IZA Evaluation Dataset Survey which contains detailed information about unemployed's job search behavior at a very early stage in their unemployment spell. Earlier studies using cross-sectional data, typically suffer from the problem of endogenous home-ownership status. People will only decide to buy a house if the expected length of stay is sufficiently long to amortize the fixed costs of buying a house (e.g. mortgage origination costs, appraisals, and costs of eventual sale). Hence, individuals in good jobs, with a low probability of becoming unemployed, are more likely to buy a home. In addition, individuals with a greater probability of becoming unemployed are also likely to have longer unemployment durations (Heckman and Borjas, 1980; Theodossiou and White, 1994). Hence, the negative correlation between home-ownership and unemployment duration in purely cross-sectional data is not causal but rather reflects characteristics inherent to the home-owner. The major advantage of our dataset is that by focusing on a sample of fresh entries into unemployment and investigating how home-ownership status affects their job search behavior and post-unemployment outcomes, the influence of selectivity bias due to different inflow probabilities into unemployment is reduced. Note that the inflow into unemployment is less likely to depend on home-ownership in Germany, because of the high replacement rate in unemployment insurances. The generous unemployment benefits do not give an incentive to avoid a (short) unemployment spell by accepting any random job offer that comes along in order to be able to pay the monthly mortgage payments.

The remainder of the paper is organized as follows. Section 2 presents an overview of earlier studies, while Section 3 briefly describes the institutional setting of the housing market in Germany. Section 4 presents the data and some descriptives, before we present our empirical approach and discuss the effects of home-ownership on job search behavior and post-unemployment outcomes in Section 5. Finally, Section 6 concludes.

\section{Previous Literature}

The first evidence on the relationship between home-ownership and aggregate unemployment rates is presented by Oswald (1999). Using data for several countries and regions, he finds that a 10 percentage point increase in the incidence of home-ownership would 
lead to a 2 percentage point increase in the unemployment rate. ${ }^{1}$ However, studies using micro level data cannot unanimously confirm this result. Green and Hendershott (2001) find similar results for several US states, though only for households with middle aged individuals. A recent study by Valetta (2013) however finds no lock in effects for US home-owners during the recent economic crisis. Other studies like Coulson and Fisher (2002), van Vuuren (2009) and Munch, Rosholm, and Svarer (2006) do not find support for the Oswald hypothesis that home-ownership raised unemployment duration in the Netherlands and Denmark, respectively.

Potential explanations for these mixed results are regional differences in price elasticities of housing supply (Zabel, 2009), loss aversions which lead to not selling the house if prices have fallen (Genesove and Mayer, 2001) or rising interest rates that makes homeowners unable to afford debt service payments on a loan that they would need to finance the purchase of a new residence (Ferreira, Gyourko, and Tracy, 2010). Moreover, Laamanen (2013) points out that home-owners are less likely to experience unemployment, but an increase in home-ownership rates causes unemployment to rise, which might be explained by externalities due to consumption reduction of home-owners. Other explanations for the non-unanimous results are based on the fact that there is considerable heterogeneity among unemployed subgroups. For example, Munch, Rosholm, and Svarer (2006) show that home-ownership in Denmark reduces job finding rates in distant labor markets but home-owners increase their employment prospects in the local labor market by setting lower reservation wages. Battu, Ma, and Phimister (2008) distinguish between private and public renting, because public rents are usually below market prices. Using data from the BHPS they find that home-ownership is a constraint for the employed, because they have a lower probability of gaining employment in more distant labor markets, while public renting is a constraint for the unemployed, because they are less likely to enter a distant job market compared to private renters. Finally, a recent study by Baert, Heylen, and Isebaert (2014) shows that home-owners with a mortgage have shorter unemployment durations than outright owners because of the liquidity constraints that provide strong incentives to find a job soon, while Kantor, Nijkamp, and Rouwendal (2012) provide evidence that leveraged home-owners are more likely to accept longer commuting distances.

\section{The German Housing Market}

Before we move on to present the data we use and our estimation approach let us briefly discuss the German housing market. The flexibility argument is high on the political agenda in Germany. In 2007/2008 about 330,000 unemployed individuals received some

\footnotetext{
${ }^{1}$ Based on this seminal work, Horsewood and Dol (2013) point out that the indebtness of households, associated with home-ownership, rather than home-ownership itself represents the major barrier to relocate for new employment.
} 
form of mobility assistance ( "Mobilitätshilfe", 53, SGB III) from the Federal Employment Agency. This includes e.g. relocation assistance, travel and commuting subsidies and subsidies to start a new household. All these components aim to remove any financial restrictions opposing starting a new job. Germany has a rather low rate of home-ownership: 44 percent of all housing in Germany between 1994 and 2001 was owner-occupied, whereas the European average was about 71 percent in this period (De Graaf, Van Leuvensteijn, and Van Ewijk, 2009). This would suggest that the German labor market is relatively flexible compared to other European countries. However, those individuals owning a house might be more immobile than those in other countries due to the institutions regarding property ownership and property transfer. First, whereas property prices have shot up at staggering rates in many industrialized countries, Germany's housing market has been characterized by rather stable housing prices for more than a decade. This is the result of a very generous tax incentive for property investors in 1991, which lead to an over-supply of property. Hence, contrary to home-owners in other European countries, German home-owners could not simply sell their homes while making a reasonable profit to cover the costs of moving. Second, there are substantial fees for real estate agents (3 to 5 percent) and property transfer taxes (4.3 to 4.7 percent) (De Graaf, Van Leuvensteijn, and Van Ewijk, 2009). As a result of this, home-ownership is likely to limit geographical mobility in Germany.

\section{Data and Descriptives}

The IZA Evaluation Dataset Survey is specifically designed to shed more light on the transition process from unemployment to employment (see Arni, Caliendo, Künn, and Zimmermann, 2014, for details) and the role active labor market policies (ALMP) can play. The dataset contains a $9 \%$ random sample from the monthly unemployment inflows, between June 2007 and May 2008, of approximately 206,000 individuals identified in the administrative records. From this gross sample of individuals aged between 16 and 54 years, representative samples of about 1,450 individuals were interviewed each month so that twelve monthly cohorts are gathered after one year. The key feature of the data set is that individuals are interviewed shortly (between 7 and 14 weeks) after they became unemployed and were asked a variety of non-standard questions which we will exploit here. In addition to measuring an extensive set of individual characteristics, labor market history and labor market outcomes, a particular strength of the survey is that it contains detailed questions about search behavior, psychological factors and also home-ownership. Altogether, a total of 17,396 interviews were obtained in this initial round of the survey (wave 1). Individuals are re-interviewed one year after entering unemployment, such that we can study their short-run employment outcomes. We restrict our sample to individuals who have become unemployed and who are still observed in the second interview. This 
leaves us with a sample of 6,940 individuals.

\section{$<$ Insert TABLE 1 ABOUT HeRE $>$}

Table 1 provides descriptive statistics of the estimation sample by home-ownership. It appears that home-owners and other unemployed differ in various respects. For example, home-owners are older, less likely to have a migration background, more likely to be female, married and to have children. ${ }^{2}$ Home-owners also spend more (life-)time in employment and have different personality characteristics.

\section{$<$ INSERT TABLE 2 ABOUt HeRE $>$}

Table 2 contains the variables related to search behavior and short-run employment outcomes for both groups. Panel A suggests that unemployed home-owners have a higher reservation wage and send out less applications compared to other unemployed. Also, they are restricted in their geographical mobility: only $20 \%$ of the home-owners applied for vacancies which would involve moving whereas this is true for $30 \%$ of the other unemployed. We do not find any differences in the total number of search channels used, but we see that home-owners use slightly less active search channels than other unemployed. ${ }^{3}$

Surprisingly, these differences do not seem to translate into different employment outcomes in wave 2 (panel B). One year after entering unemployment both groups of unemployed are equally likely to be employed (around 64\%) and have participated in ALMP at a similar rate (29\%). Although home-owning unemployed need slightly more time until they find suitable re-employment, their search seems to pay off. Although they have moved less than others searching for a job, home-owning unemployed managed to have a higher wage and are more satisfied with their new job (Panel $\mathrm{C}$ ).

\section{Estimation Results}

As shown in the previous section, there are significant differences between home-owners and other unemployed with respect to their job search behavior and subsequent labor market outcomes. However, given the different distribution of observable characteristics in both groups, one should be cautious in interpreting these differences. Besides having

\footnotetext{
${ }^{2}$ Because of these differences, it would be interesting to estimate the effect of home-ownership for various subsamples (e.g. men vs. women, married vs. single). Unfortunately, the number of observations becomes too small if we would do this. Therefore we estimate our models for the pooled sample, where we control for a rich set of observable characteristics.

${ }^{3}$ The survey question regarding the use of search channels is designed as a multiple choice answer, where ten alternatives were offered. We define active search methods as those that individuals would consult if they wanted to solicit specific predefined types of jobs, rather than reacting to job opportunities that come up at random. This includes: Posting an advertisement oneself, contacting a private agent without voucher, and direct application at companies.
} 
direct consequences for the labor market performance, the differences between both groups might affect households preferences for labor market mobility and their likelihood of homeownership simultaneously. ${ }^{4}$ In order to single out the effect of home-ownership as good as possible, we exploit a propensity score matching strategy.

Using the matching estimator as a tool to perform decompositions instead of estimating average treatment effects is similar in spirit to the papers by Frölich (2007), Nopo (2008) or Caliendo and Lee (2013). Unlike the standard application of matching in the treatment evaluation literature, it is not strictly necessary that the conditional independence assumption holds in our case. Any unobservable difference falls into the residual term. Clearly, this comes at the price that causality needs to be interpreted more carefully here, also because owning a house is not exactly a treatment variable, but rather a choice variable. Our aim is to make unemployed home-owners and other unemployed individuals as comparable as possible based on an extensive set of observable characteristics, including inter alia socio-demographic and household characteristics, education variables, the labor market history, personality charcteristics and regional information (see again Table 2 for a full set of control variables). Based on that, differences in outcome variables among unemployed can more easily be attributed to home-ownership.

First, we estimate the probability of being a home-owner in Table 3 with a logit model. The results indicate that, among other differences, home-owners are less likely to have a migration background, live in areas with a low local unemployment rate, and are more likely to be married, have children and a higher education. The resulting propensity score distribution is shown in Figure 1. Even though there is a huge overlap in the distribution, both groups differ in the bounds, such that a proper imposition of the common support seems important and using OLS is more likely to produce biased estimates.

\section{$<$ Insert TABle 3 And Figure 1 ABOUt HeRE $>$}

Based on the estimated propensity score we apply a kernel matching procedure for two reasons. First, it achieves a lower variance by using more information to construct the counterfactual outcomes. Second, it allows us to circumvent the problems associated with nearest-neighbor matching (Abadie and Imbens, 2008). To be more specific we use an Epanechnikov kernel with a bandwidth of $0.06 .^{5}$ The matching results are presented in Table 4 where it can also be seen that the matching procedure is very successful in balancing the characteristics of both groups. ${ }^{6}$ Panel A shows that home-owning unem-

\footnotetext{
${ }^{4}$ For example, Van Leuvensteijn and Koning (2004) and Munch, Rosholm, and Svarer (2008) have shown that home-owners in general have a lower probability of becoming unemployed. Moreover, modeling the housing and migration choice to control for omitted variables and reverse causality issues, Winkler (2010) finds that home-ownership has a large negative effect on the probability of moving in response to a labor market shock.

${ }^{5}$ Results are not sensitive to the choice of the kernel, bandwidth or matching algorithm. Sensitivity results are available on request from the authors.

${ }^{6}$ The mean and median standardized bias is below $1 \%$ for the first and second panel, and below $3 \%$ for the third panel (see Caliendo and Kopeinig, 2008, for details on matching quality criteria).
} 
ployed do not differ significantly in terms of search intensity or type of search from their non-home-owning counterparts. If anything they seem to search less intensively and use less active search channels (both variables not significant). They are, however, indeed restricted in their mobility; not only do they report to be less willing to move for a new job, also their actual moving behavior is limited compared to others. ${ }^{7}$ Hence, they search for jobs within a smaller geographically defined area which might explain why they would send out less applications. Panel B shows that this limited mobility results in lower employment probabilities in the short run (about 3 percentage points in wave 1 ). However, one year later the difference in employment probabilities has vanished. On top of that, home-owners found jobs which pay higher wages and in which job satisfaction is higher (Panel C). These results are in line with earlier findings for the US by Coulson and Fisher (2002).

\section{$<$ INSERT TABLE 4 ABOUt HeRE $>$}

When we do the analyzes by gender the results are not much different. ${ }^{8}$ All in all, we cannot find evidence that unemployed home-owners are being punished for their limited geographical mobility in Germany.

\section{Conclusions}

This paper investigates to what extent home-ownership limits the possibilities for unemployed to exit unemployment and to find a new job. Using the IZA Evaluation Dataset Survey - a panel data set of newly unemployed individuals in Germany - we find that unemployed home-owners are less willing to move, but that this does not affect their job search behavior otherwise. They do not compensate their mobility restriction by more intensive (i.e. more search channels or applications) or different (more active/informal channels) job search. Furthermore, home-ownership does not seem to affect post-unemployment outcomes one year after entering unemployment negatively. In fact, we find that home-owning unemployed find better re-employment jobs than their renting counterparts. Hence, the limited mobility due to home-ownership does not force individuals to accept worse jobs. If home-owners would change their search behavior or face specific difficulties in finding a new job due to their restricted mobility, ALMP might have to be adjusted to address these problems. However, since both job search behavior and post-unemployment job outcomes are not negatively affected, the German labor market does not call for such an intervention.

\footnotetext{
${ }^{7}$ This corresponds to earlier findings for the UK by Battu, Ma, and Phimister (2008).

${ }^{8}$ Results available from the authors upon request.
} 


\section{References}

Abadie, A., And G. Imbens (2008): "On the Failure of the Bootstrap for Matching Estimators," Econometrica, 76(6), 1537-1557.

Arni, P., M. Caliendo, S. KÜnn, and K. Zimmermann (2014): "The IZA Evaluation Dataset Survey: A Scientific Use File," IZA Journal of European Labor Studies, 3:6.

Baert, S., F. Heylen, and D. Isebaert (2014): "Does homeownership lead to longer unemployment spells? The role of mortgage payments," De Economist, 162, 263-286.

Battu, H., A. Ma, And E. Phimister (2008): "Housing tenure, job mobility and unemployment in the UK," The Economic Journal, 118, 311-328.

Blanchflower, D., And A. Oswald (2013): "Does high homeownership impair the labor market," Working Paper 19079, NBER.

Caliendo, M., And S. Kopeinig (2008): "Some Practical Guidance for the Implementation of Propensity Score Matching," Journal of Economic Surveys, 22(1), 31-72.

Caliendo, M., And W. Lee (2013): "Fat Chance! Obesity and the Transition from Unemployment to Employment," Economics and Human Biology, 11(2), 121-133.

Coulson, N., And L. Fisher (2002): "Tenure choice and labour market outcomes," Housing Studies, 17(1), 35-49.

(2009): "Housing tenure and labor market impacts: The search goes on," Journal of Urban Economics, 65(3), 252-264.

De Graaf, T., M. Van Leuvensteijn, and C. Van EwiJk (2009): "Homeownership, social renting, and labour mobility across Europe," in Homeownership \& the labour market in Europe, ed. by C. Van Ewijk, and M. V. Leuvensteijn, pp. 113-136. Oxford University Press.

DiPasquale, D., and E. Glaeser (1999): "Incentives and social capital: Are homeowners better citizens?," Journal of Urban Economics, 45(2), 354-384.

Ferreira, F., J. Gyourko, and J. Tracy (2010): "Housing busts and household mobility," Journal of Urban Economics, 68, 34-45.

Frölich, M. (2007): "Propensity score matching without conditional independence assumption - with an application to the gender wage gap in the United Kingdom," Econometrics Journal, 10, 359-407.

Genesove, D., And C. Mayer (2001): "Loss aversion and seller behavior: Evidence from the housing market," Quarterly Journal of Economics, 87, 1233-1260.

Glaeser, E., And J. Shapiro (2003): "The benefits of the home mortgage interest deduction," Tax Policy and the Economy, 17, 37-82.

Green, R., And P. Hendershott (2001): "Home-ownership and unemployment in the US," Urban Studies, 38(9), 1509-1520.

Heckman, J., and G. BorJas (1980): "Does unemployment cause future unemployment? Definitions, questions, and answers from a continuous time model of heterogeneity and state dependence," Economica, 47, 247-283. 
Horsewood, N., And K. Dol (2013): "Home ownership, mobility and unemployment: A re-evaluation of the Owswald thesis," Neujobs Working Paper 14.3a.

Kantor, Y., P. NiJkamp, and J. Rouwendal (2012): "Homeownership, unemployment and commuting distances," Tinbergen Institute Discussion Paper 13-144/VIII.

LaAmanen, J.-P. (2013): "Home-ownership and the Labour Market: Evidence from Rental Housing Market Deregulation," MPRA Working Paper 55256.

Morescalchi, A. (2014): "The puzzle of job search and housing tenure. A reconciliation of theory and empirical evidence," Working Paper 59079, Munich Personal RePec Archive.

Munch, J., M. Rosholm, And M. Svarer (2006): "Are homeowners really more unemployed?," The Economic Journal, 116, 991-1013.

(2008): "Home ownership, job duration, and wages," Journal of Urban Economics, 63, 130-145.

Nopo, H. (2008): "Matching as a Tool to Decompose Wage Gaps," Review of Economics and Statistics, 90, 290-299.

Oswald, A. (1999): "The housing market and europe's unemployment: A non-technical paper," Working paper, Warwick University, Warwick.

Theodossiou, I., And M. White (1994): "Unemployment propensity and unemployment duration," Labour, 8, 445-454.

VAletta, R. (2013): "House lock and structural unemployment," Labour Economics, 25, $86-97$.

Van Leuvensteijn, M., And P. Koning (2004): "The effect of home-ownership on labor mobility in the Netherlands," Journal of Urban Economics, 55, 580-596.

VAN VuURen, A. (2009): "The impact of homeownership on unemployment in the Netherlands," in Homeownership \& the labour market in Europe, ed. by C. Van Ewijk, and M. V. Leuvensteijn, pp. 113-136. Oxford University Press.

WinkLER, H. (2010): "The effect of homeownership on geographic mobility and labor market outcomes," Mimeo, UCLA.

ZABEL, J. (2009): "The role of the housing market in the migration response to employment shocks," Working paper. 
Table 1: Selected Descriptive Statistics by Home Ownership

\begin{tabular}{|c|c|c|c|}
\hline \multirow[b]{2}{*}{ Variable } & \multicolumn{2}{|c|}{ Homeowner } & \multirow{2}{*}{$\begin{array}{c}t t \text {-test } \\
p \text {-value }\end{array}$} \\
\hline & No & Yes & \\
\hline No. of observations & 4230 & 2710 & \\
\hline \multicolumn{4}{|l|}{ Socio-Demographic and Household Characteristics } \\
\hline West Germany & 0.70 & 0.69 & 0.29 \\
\hline Female & 0.48 & 0.52 & 0.00 \\
\hline Migration background 2 ( $1=$ yes $)$ & 0.14 & 0.10 & 0.00 \\
\hline German citizenship & 0.95 & 0.97 & 0.00 \\
\hline Age & 34.39 & 37.64 & 0.00 \\
\hline Married (or cohabiting) & 0.30 & 0.53 & 0.00 \\
\hline \multicolumn{4}{|l|}{ Children } \\
\hline No children & 0.71 & 0.58 & 0.00 \\
\hline One child & 0.18 & 0.22 & 0.00 \\
\hline Two (or more) children & 0.11 & 0.20 & 0.00 \\
\hline \multicolumn{4}{|l|}{ Employment status partner: } \\
\hline None & 0.34 & 0.25 & 0.00 \\
\hline Full-time Employed & 0.40 & 0.52 & 0.00 \\
\hline Part-time Employed & 0.07 & 0.08 & 0.28 \\
\hline School, Apprentice, etc. & 0.07 & 0.06 & 0.01 \\
\hline Unemployed & 0.04 & 0.03 & 0.00 \\
\hline Other & 0.07 & 0.07 & 0.94 \\
\hline \multicolumn{4}{|l|}{ Education } \\
\hline \multicolumn{4}{|l|}{ School leaving degree } \\
\hline None, special needs, other & 0.03 & 0.02 & 0.09 \\
\hline Lower secondary school & 0.27 & 0.27 & 0.64 \\
\hline Middle secondary school & 0.39 & 0.45 & 0.00 \\
\hline Specialized upper secondary school & 0.31 & 0.26 & 0.00 \\
\hline \multicolumn{4}{|l|}{ Vocational training } \\
\hline None & 0.10 & 0.08 & 0.00 \\
\hline Internal or external professional training, others & 0.67 & 0.71 & 0.00 \\
\hline Technical college or university degree & 0.23 & 0.21 & 0.15 \\
\hline \multicolumn{4}{|l|}{ Labor Market History } \\
\hline \multicolumn{4}{|l|}{ Employment status before unemployment } \\
\hline Employed & 0.65 & 0.63 & 0.06 \\
\hline Subsidized employment & 0.06 & 0.07 & 0.13 \\
\hline School, apprentice, military, etc. & 0.18 & 0.16 & 0.02 \\
\hline Maternity leave & 0.03 & 0.05 & 0.00 \\
\hline Other & 0.08 & 0.09 & 0.03 \\
\hline Unemployment benefit recipient (1=yes) & 0.77 & 0.72 & 0.00 \\
\hline Months in unemployment (div. by age-18) & 0.80 & 0.66 & 0.00 \\
\hline Months in employment (div. by age-18) & 7.72 & 8.32 & 0.01 \\
\hline Seeking self-employment & 0.05 & 0.06 & 0.13 \\
\hline \multicolumn{4}{|l|}{ Personality Characteristics $(1=$ low, $7=$ high $)$} \\
\hline Openness & 5.09 & 4.95 & 0.00 \\
\hline Conscientiousness & 6.21 & 6.21 & 0.86 \\
\hline Extraversion & 5.20 & 5.10 & 0.00 \\
\hline Neuroticism & 3.74 & 3.79 & 0.09 \\
\hline Internal Locus of Control & 5.04 & 5.01 & 0.07 \\
\hline \multicolumn{4}{|l|}{ Regional and Seasonal Variables } \\
\hline \multicolumn{4}{|l|}{ Local UE Rate at Interview } \\
\hline below $5 \%$ (ref.) & 0.22 & 0.22 & 0.91 \\
\hline $5-10 \%$ & 0.43 & 0.45 & 0.06 \\
\hline $10-15 \%$ & 0.28 & 0.24 & 0.00 \\
\hline $15+\%$ & 0.07 & 0.09 & 0.01 \\
\hline \multicolumn{4}{|l|}{ Time between UE and interview: ( 7 to $14+$ weeks) } \\
\hline 7 weeks & 0.02 & 0.02 & 0.67 \\
\hline 8 & 0.23 & 0.24 & 0.36 \\
\hline $\begin{array}{l}(\ldots) \\
\text { Months of entry (June } 2007 \text { - May 2008) }\end{array}$ & & & \\
\hline \multicolumn{4}{|l|}{ Months of entry (June 2007 - May 2008) } \\
\hline$(\ldots)$ & 0.05 & 0.05 & 0.31 \\
\hline
\end{tabular}

Source: IZA Evaluation Data Set, own calculations.

Note: All numbers are shares unless stated otherwise; $p$-value refers to a two-sided $t$-test of mean equality between both groups. 
Table 2: Search and Employment Outcome Variables by Home Ownership

\begin{tabular}{|c|c|c|c|}
\hline \multirow[b]{2}{*}{ Variable } & \multicolumn{2}{|c|}{ Homeowner } & \multirow{2}{*}{$\begin{array}{l}t \text {-test } \\
p \text {-value }\end{array}$} \\
\hline & No & Yes & \\
\hline No. of observations & 4230 & 2710 & \\
\hline \multicolumn{4}{|l|}{ A. Search Variables } \\
\hline Hourly reservation wage (in Euro) ${ }^{(a)}$ & 7.17 & 7.39 & 0.06 \\
\hline Number of own applications (mean) & 15.15 & 13.82 & 0.03 \\
\hline Number of search channels & 4.76 & 4.78 & 0.67 \\
\hline Active search channels ( $0=$ low, $4=$ high $)$ & 0.98 & 0.92 & 0.00 \\
\hline Applied for vacancies for which you would have to move & 0.30 & 0.20 & 0.00 \\
\hline \multicolumn{4}{|l|}{ B. Employment and ALMP Variables in Wave 2} \\
\hline Moved between wave 1 and $2(1=$ yes $)$ & 0.07 & 0.02 & 0.00 \\
\hline Employed at wave 1 & 0.24 & 0.21 & 0.00 \\
\hline Employed at wave 2 & 0.64 & 0.64 & 0.74 \\
\hline Participation in any ALMP & 0.29 & 0.29 & 0.64 \\
\hline Participation in ALMP training program & 0.20 & 0.19 & 0.34 \\
\hline Months employed until wave 2 & 5.33 & 4.96 & 0.00 \\
\hline Months not employed until wave 2 & 6.82 & 6.97 & 0.07 \\
\hline \multicolumn{4}{|l|}{ C. Job Related Variables in Wave $2^{(\mathrm{b})}$} \\
\hline Hourly wage in wave 2 (in Euro) & 8.32 & 8.59 & 0.16 \\
\hline Commuting distance to job (in $\mathrm{km}$ ) & 42.29 & 43.37 & 0.81 \\
\hline Job satisfaction with first job (0:low, 10:high) & 7.05 & 7.42 & 0.00 \\
\hline
\end{tabular}

Source: IZA Evaluation Data Set, own calculations.

Note: All numbers are shares unless stated otherwise; $p$-value refers to a two-sided $t$-test of mean equality between both groups.

(a) Reservation wages are observed for a smaller number of individuals only, e.g., those who are still unemployed at the first interview.

(b) These variables are observed for a smaller number of individuals only, e.g., those who have found a job. 
Table 3: Propensity Score Estimation

\begin{tabular}{|c|c|c|}
\hline Variable & $\begin{array}{l}\text { Coefficients } \\
\text { (1) }\end{array}$ & $\begin{array}{c}\text { (s.e.) } \\
(2)\end{array}$ \\
\hline \multicolumn{3}{|c|}{ Socio-Demographic and Household Characteristics } \\
\hline West Germany & $-.399^{* * *}$ & $(0.109)$ \\
\hline Female & -.064 & $(0.061)$ \\
\hline Migration background ( $1=$ yes) & $-.380^{* * *}$ & $(0.1)$ \\
\hline German citizenship & $0.488^{* * *}$ & $(0.174)$ \\
\hline \multicolumn{3}{|l|}{ Age } \\
\hline \multicolumn{3}{|l|}{ 17-24 years } \\
\hline $25-34$ years & $-.763^{* * *}$ & $(0.091)$ \\
\hline $35-44$ years & $-.236^{* *}$ & $(0.096)$ \\
\hline $45-55$ years & $0.195^{* *}$ & $(0.098)$ \\
\hline Married (or cohabiting) & $0.973^{* * *}$ & $(0.076)$ \\
\hline \multicolumn{3}{|l|}{ Children (Ref.: No children) } \\
\hline One child & $0.315^{* * *}$ & $(0.072)$ \\
\hline Two (or more) children & $0.613^{* * *}$ & $(0.087)$ \\
\hline \multicolumn{3}{|l|}{ Employment status partner: } \\
\hline \multicolumn{3}{|l|}{ No partner (ref.) } \\
\hline Full-time employed & -.082 & $(0.078)$ \\
\hline Part-time employed & $-.525^{* * *}$ & $(0.123)$ \\
\hline Education & -.034 & $(0.117)$ \\
\hline Unemployment & $-.760^{* * *}$ & $(0.163)$ \\
\hline Other & $-.603^{* * *}$ & $(0.128)$ \\
\hline \multicolumn{3}{|l|}{ Education } \\
\hline \multicolumn{3}{|l|}{ School leaving degree } \\
\hline \multicolumn{3}{|l|}{ None, special needs, other (Ref.) } \\
\hline Lower secondary school & 0.131 & $(0.189)$ \\
\hline Middle secondary school & 0.208 & $(0.189)$ \\
\hline Specialized upper secondary school & 0.036 & $(0.194)$ \\
\hline \multicolumn{3}{|l|}{ Higher Education } \\
\hline \multicolumn{3}{|l|}{ None (Ref.) } \\
\hline Int. or ext. prof. training, others & $0.17^{*}$ & $(0.097)$ \\
\hline Technical college or university degree & 0.181 & $(0.115)$ \\
\hline \multicolumn{3}{|l|}{ Labor market history } \\
\hline \multicolumn{3}{|l|}{$\begin{array}{l}\text { Employment status before Unemployment } \\
\text { Employed (ref.) }\end{array}$} \\
\hline Subsidized employment & 0.13 & $(0.11)$ \\
\hline School, apprentice, military, etc. & $0.267^{* * *}$ & $(0.095)$ \\
\hline Maternity leave & 0.066 & $(0.14)$ \\
\hline Other & 0.16 & $(0.099)$ \\
\hline Unemployment Benefit Recipient (yes) & $-.321^{* * *}$ & $(0.122)$ \\
\hline Level of UB in Euro/month & -.009 & $(0.018)$ \\
\hline Months in unemployment (div. by age-18) & $-.058^{* * *}$ & $(0.022)$ \\
\hline Months in employment (div. by age-18) & $0.009^{*}$ & $(0.005)$ \\
\hline Seeking self-employment & 0.126 & $(0.12)$ \\
\hline \multicolumn{3}{|l|}{ Personality Characteristics } \\
\hline Openness (standardized) & $-.078^{* * *}$ & $(0.03)$ \\
\hline Conscientiousness (standardized) & 0.017 & $(0.03)$ \\
\hline Extraversion (standardized) & $-.060 * *$ & $(0.03)$ \\
\hline Neuroticism (standardized) & 0.022 & $(0.03)$ \\
\hline Locus of control (standardized) & -.005 & $(0.03)$ \\
\hline \multicolumn{3}{|l|}{ Regional and Seasonal Variables } \\
\hline \multicolumn{3}{|l|}{$\begin{array}{l}\text { Local Unemployment Rate at Interview } \\
\text { below } 5 \% \text { (ref.) }\end{array}$} \\
\hline $5-10 \%$ & 0.02 & $(0.069)$ \\
\hline $10-15 \%$ & $-.524^{* * *}$ & $(0.116)$ \\
\hline $15+\%$ & $-.288^{*}$ & $(0.154)$ \\
\hline Obs. & 6940 & \\
\hline Pseudo- $\mathrm{R}^{2}$ & 0.093 & \\
\hline log-Likelihood & -4211.598 & \\
\hline
\end{tabular}

Source: IZA Evaluation Data Set, own calculations.

Note: Additional control variables used: Month of entry into unemployment (June 2007-May2008) and time between unemployment entry and interview (7-14 weeks). Full estimation results are available on request by the authors.

$* * * / * * / *$ indicate significance at the $1 \% / 5 \% / 10 \%$-level, standard errors in parentheses. 
Table 4: Propensity Score Matching Results ${ }^{1}$

\begin{tabular}{|c|c|c|c|c|c|c|c|c|}
\hline Outcome Variables & Effect & se & $\mathrm{t}$ & $\mathrm{TN}^{2}$ & $\mathrm{NT}^{2}$ & $\mathrm{Off}^{2}$ & biasaft $^{2}$ & mdbaft $^{2}$ \\
\hline \multicolumn{9}{|l|}{ A. Search Variables } \\
\hline Number own applications & -0.4090 & 0.6031 & -0.6782 & 2710 & 4230 & 6 & 0.7213 & 0.6672 \\
\hline Number of search channels & 0.0580 & 0.0530 & 1.0930 & 2710 & 4230 & 6 & 0.7213 & 0.6672 \\
\hline Applied for vacancies for which you would have to move & -0.0451 & 0.0109 & -4.1340 & 2710 & 4230 & 6 & 0.7213 & 0.6672 \\
\hline Log hourly reservation wage (in Euro) ${ }^{(a)}$ & 0.0117 & 0.0133 & 0.8797 & 1899 & 2904 & 9 & 0.8778 & 0.7197 \\
\hline \multicolumn{9}{|l|}{ B. Employment and ALMP Variables } \\
\hline Employed in wave 1 & -0.0281 & 0.0111 & -2.5254 & 2710 & 4230 & 6 & 0.7213 & 0.6672 \\
\hline Employed in wave 2 & 0.0036 & 0.0126 & 0.2880 & 2710 & 4230 & 6 & 0.7213 & 0.6672 \\
\hline Participation in any ALMP until wave 2 & -0.0049 & 0.0129 & -0.3789 & 2710 & 4230 & 6 & 0.7213 & 0.6672 \\
\hline Participation in ALMP training program until wave 2 & -0.0124 & 0.0114 & -1.0861 & 2710 & 4230 & 6 & 0.7213 & 0.6672 \\
\hline Months employed until wave 2 & -0.1358 & 0.1325 & -1.0273 & 2710 & 4230 & 6 & 0.7213 & 0.6672 \\
\hline Months not employed until wave 2 & 0.0079 & 0.1143 & 0.0691 & 2710 & 4230 & 6 & 0.7213 & 0.6672 \\
\hline \multicolumn{9}{|l|}{ C. Job Related Variables ${ }^{(b)}$} \\
\hline Log hourly wage in wave 2 & 0.0398 & 0.0169 & 2.355 & 1648 & 2617 & 9 & 1.7573 & 1.3438 \\
\hline Job satisfaction with first job (0:low, 10:high) & 0.3456 & 0.0946 & 3.6554 & 1302 & 2102 & 13 & 2.6811 & 2.1023 \\
\hline
\end{tabular}

Source: IZA Evaluation Data Set, own calculations.

Note: Results presented here a based on a kernel matching algorithm with an epanechnikov kernel function, a bandwidth of 0.06 and imposition of common support; standard errors are based on 499 bootstrap replications.

(1) Propensity score estimation results are available in Table 3 and the propensity score distribution is shown in Figure 1.

(2) TN and NT indicate the number of individuals in the group of homeowners and non-homeowners; Off counts the number of individuals outside the common support region. biasaft and mdbaft summarize the mean and median standardized bias after matching.

(a) Reservation wages are observed for a smaller number of individuals only, e.g., those who are still unemployed in wave 1.

(b) These variables are observed for a smaller number of individuals only, e.g., those who have found a job. 
Figure 1: Propensity Score Distribution

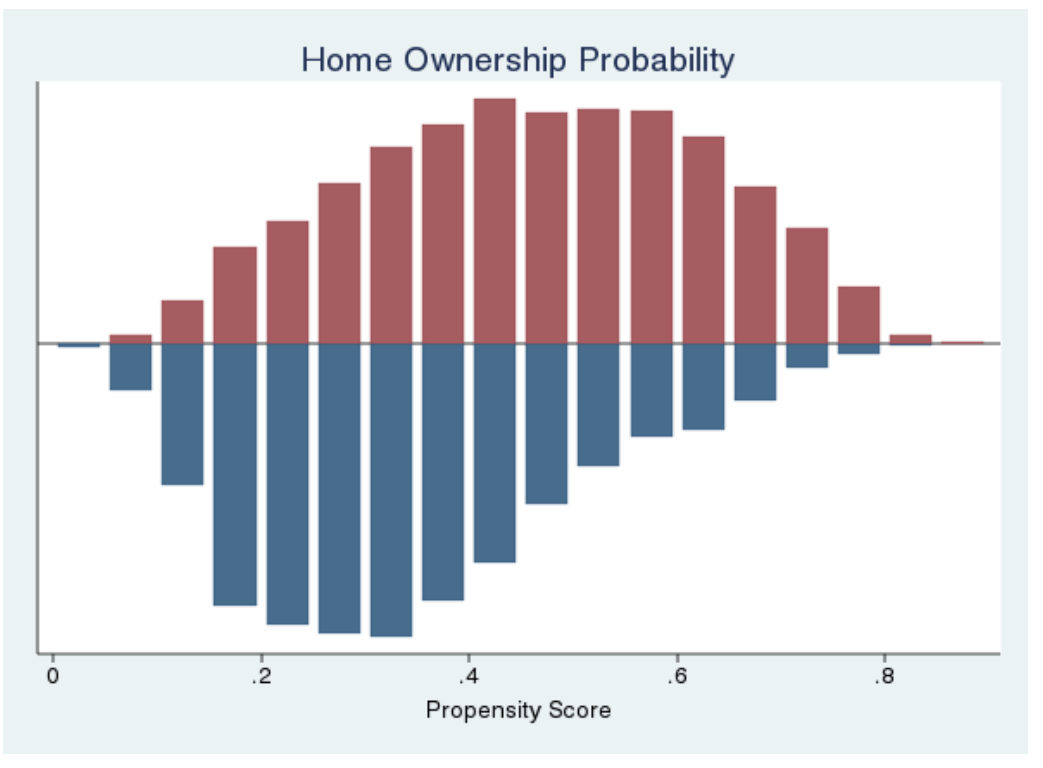

Source: IZA Evaluation Dataset, own calculations.

Note: Upper half depicts home owners; lower half refers to non home owners. 